\title{
Farm Conflict in France and the Europeanisation of Agricultural Policy
}

\author{
Christilla Roederer-Rynning, Post-Doctoral Research Fellow \\ Institute of Political Science, University of Copenhagen \\ Rosenborggade 15 - 1130 Copenhagen $\mathrm{K}$. \\ Denmark \\ Tel: (45) 35323440 \\ Fax: (45) 35323399 \\ Email: crr@ifs.ku.dk
}

Paper prepared for presentation at the European Community Studies Association (ECSA)

Seventh Biennial International Conference, May 31-June 2, 2001, Madison, Wisconsin.

The author would like to acknowledge the support provided by the National Science Foundation (doctoral dissertation research improvement grant SBR-9810701). 


\section{Farm Conflict in France and the Europeanisation of Agricultural Policy}

This paper investigates farm conflict in France from 1958 to the present in relation to broader dynamics of Europeanisation and globalisation. The framework emphasises the role of institutions in affecting social conflict by shaping world-views, mediating economic forces, and structuring the political opportunities of contending groups. The analysis investigates the relationship between institutional politics and contentious politics at three junctures of the development of the CAP corresponding to: its formation (1958-1969), consolidation (1970-1987), and reform (1988 to present). The findings suggest that European institutions have played a significant. role in the production and transformation of farm conflict in France.

As analysts are taking stock of the fast-growing literature on Europeanisation, it has become evident that two issues have been neglected in the debate. The first concerns the interaction between European processes and domestic politics. Tocqueville once noted that traditional political structures could survive even the most revolutionary changes. A fortiori, Europeanisation, defined broadly as 'the development and sustaining of systematic European arrangements to manage cross-border connections, ${ }^{1}$, need not mean the replacement of domestic political processes and structures with European ones. European processes may foster the persistence of existing domestic political patterns or conversely transform them. More light must be shed on the conditions triggering these effects. ${ }^{2}$ The second lacuna concerns the relationship between Europeanisation and globalisation. ${ }^{3}$ Among other signs, the Danish referendum on the Euro signalled that the role of the European Union (EU) in mediating the effects of globalisation has become a central concern of the political debate in 
the EU. At present, however, we know little about the ways in which the EU filters and nourishes dynamics of globalisation.

These issues intersect in many ways. Europeanisation may represent the European projection of national solutions in response to globalisation, thereby enabling the reproduction of domestic political patterns within an insulated zone. European policies may also prompt innovative practices challenging the traditional boundaries of politics, and even fuelling globalisation. This analysis attempts to shed light on the interactions of global, European, and national processes by exploring the role of institutions. Whether and how domestic political frames and practices are transformed by Europeanisation and globalisation depends on the institutionalisation of these processes. Institutions are organised meanings reproduced in more or less solidified routines. 'Living' institutions learn their place in their political-economic environment and leave their mark on it. ${ }^{4}$

The role of institutional arrangements is analyzed through the case of farm protest in France. Whereas farm protest has often been attributed to local and national dynamics, its connections to the EU's Common Agricultural Policy (CAP) and international trade negotiations have been manifest on several occasions. ${ }^{5}$ Simultaneously, protest raises the issue of change and continuity in farm politics in France. Farm politics represents an exception in the pattern of interest intermediation in France. While comparativists have often singled out France as a peculiarly resilient case of interest group pluralism, ${ }^{6}$ farm politics is organised along distinctly corporatist features: it is an exception in the exception. ${ }^{7}$ The questions arising are thus the following. Does farm protest represent a critique or the popular arm of agricultural corporatism? And to what extent are changes in the role of protest related to dynamics of Europeanisation and / or globalisation? 
The analysis is based on a comparison of protest patterns in three periods of the development of the CAP: its formative years (1958-1969); its consolidation (1970-1987); and its reform (1988 to present) ${ }^{8}$. This comparison suggests that distinct historical arrangements in agricultural policy have played different roles in mediating broader international dynamics while enabling in varying degrees the reproduction of domestic political structures and practices.

\section{INSTITUTIONAL MEDIATIONS}

Since Scott and Meyer's seminal works in organisation sociology, analysts have been accustomed to drawing a distinction between 'technical' and 'institutional' environments. Technical environments are characterised by the predominance of competition as a mechanism of allocation of resources and of efficiency as a guiding principle of action. In institutional environments, on the other hand, rules and requirements shape exchange, and support requires above all conforming to these rules rather than pursuing efficiency. Institutions are complex packages of standard operating procedures, codes of meaning, and resources. ${ }^{9}$ These packages filter pressures for change emanating from political and economic actors: 'institutions constrain and refract politics': ${ }^{10}$ Studying the rise of neoliberalism in North America and Western Europe in the last two decades and its spread to former Communist countries, Campbell, Pedersen and their colleagues have thus identified a series of institutional factors-formal rules, discourse, resource endowments-'mediat[ing] the spread or incursion of a neoliberal logic within a particular context, system or field'. ${ }^{11}$ On the European continent, there is also evidence that the existence of highly institutionalised crossborder arrangements within the EU and NATO has embedded meanings and procedures, 
which have shaped the creation of post cold war international organisations ${ }^{12}$ while inducing some degree of homogenisation of member-states ${ }^{\dagger}$ public policies. ${ }^{13}$

Institutional mediations, that is the independent role of institutions in constraining and refracting environmental pressures, take place through various mechanisms. Institutions are carriers of meanings, codes of conduct, or cognitive frames, that is 'coherent systems of normative and cognitive elements which define, in a given field, "world views", mechanisms of identity formation, principles of action, as well as methodological prescriptions and practices for actors subscribing to the same frame'. ${ }^{14}$ Cognitive frames influence actors' perception of the world, beliefs on causality, and preferences. ${ }^{15}$ For example, concerted efforts to accelerate the transition of former Communist countries were guided by discernable collective meanings of 'Europe' and 'liberal democracy', which eliminated schemes excluding the United-States or privileging state intervention. ${ }^{16}$

Frames are forged and embedded in a series of rules and standard operating procedures. These rules are constituted through experiential learning and contribute to reducing the uncertainties stemming from conflicting or changing environmental signals. Rules and procedures support the generation of an 'institutional memory', which constrains the extent to which 'different participants can use past events, promises, goals, assumptions, behavior, etc. in different ways'. ${ }^{17}$ Simultaneously, rules and procedures introduce organisational biases into the decision-making process, by determining who participates in the process and on what bases. The sixth intergovernmental conference (IGC) that gave birth to the Amsterdam Treaty in October 1997 brought these organisational factors clearly into focus. Italian conveners attempted to suggest historical analogies between the IGC and the Messina conference in 1955 in order to erase bad memories of the Maastricht negotiations and elicit visionary participation from policy-makers. Yet, these efforts did not suffice to 
disrupt the policy sequence encoded in the Maastricht Treaty. By calling upon policy-makers to convene an IGC, the Maastricht Treaty had not only defined the issues to be addressed during the IGC but also the organisational format to be adopted-both factors which proved very constraining during the IGC. ${ }^{18}$

Finally, resources and capabilities are tied to organised meanings. ${ }^{19}$ Resource endowments, in terms of staffs, budgets, buildings and equipment, contribute to 'upholding specific interpretations and worldviews' by giving teeth to ideas. ${ }^{20}$ Resources enable the entrenchment, and provide tangible evidence, of institutional world-views. They are an indispensable component of 'depersonalised authority' because they signal opportunities and sanctions to political and economic actors, and urge them to conform to institutionalised rules and meanings. ${ }^{21}$ For example, the entrenchment of new financial practices in the EU corresponded with the creation of the European Court of Auditors (ECA) in 1977 and its subsequent elevation to the status of full institution in 1992. While auditing functions were previously carried out by a staff of 40 in the European Commission's Audit Board, the ECA's substantially enhanced means (a staff of 500 in 1995) enabled it to develop strong auditing norms and coherent operating procedures, which eventually strengthened the paradigm of 'sound financial management'. 22

These three dimensions help 'measure' degrees of institutionalisation, which in turn provides a rough indicator of the ability of institutions to constrain and refract environmental incentives. It is almost a tautology, but it is worthwhile to state it: the more institutionalised a paradigm is, the more path-dependent policy outcomes and the less responsive the policy process will be. Under these conditions, change is likely to be provoked by 'dramatic crises and external shocks', ${ }^{23}$ coupled with a 'major political-cultural shift'. ${ }^{24}$ 
According to historical institutionalists, change itself may take place through the emergence of new actors or new goals in existing institutions or the sudden salience of existing institutions in response to changes in the environment. ${ }^{25}$ Though appealing, these explanations often run the risk of "treat[ing] institutional change as a product of impersonal forces' or on the contrary 'as a product of the insight and will of a single individual'. ${ }^{26}$ To eschew this dilemma, Pontusson proposed to reintroduce 'the notion of collective actors, conceived as groups of individuals who share certain interests and who are tied to each other by more or less formal and more or less permanent organisations' ${ }^{27}$ Contemporary social movement research helps specify this insight by pointing to the dialectic relationship between institutions and collective action. Through collective action, ordinary people 'open new political spaces, build collective identities and transform the values of civil society'. ${ }^{28}$ However, the institutional context mediates this effect by 'provid[ing] incentives for people to undertake collective action by affecting their expectations for success of failure'. ${ }^{29}$ The concept of political opportunity structure suggests that institutions affect popular mobilisation by shaping access through formal rules and informal mechanisms such as the availability of influential allies and the existence of division among elites. ${ }^{30}$

The following analysis explores the relationship between the CAP as an institution, popular mobilisation, and policy change. It shows how the organisation, resources, and meanings underpinning the CAP constrained policy outcomes not only by creating path dependent effects but also by refracting farm conflict. The argument proceeds through a comparison of the institutional set-up and farm conflict at three crucial junctures of the CAP. 
IN SEARCH OF A EUROPEAN FRAMEWORK, 1958-1969

The Agricultural Policy Regime

The CAP took shape from 1958 to 1969 through a succession of protracted negotiations. Until 1965, the policy framework was at the core of intergovernmental negotiations, while an agreement on the financial structure of the CAP, blocked during the Luxembourg crisis, had to wait until the resignation of General de Gaulle in 1969. Pompidou, the new French president, was more accommodating of the demands made by his European partners. At the end of the year, he traded off the creation of 'own resources' against the securing of intergovernmental control over agriculture expenditure in a deal establishing the famous distinction between 'compulsory' and 'non-compulsory' expenditure. ${ }^{31}$

While member-states were engaged in European negotiations, farm policy remained under the jurisdiction of national authorities and reflected post-war domestic arbitrages. The mechanisation of agriculture was an important orientation of post-war modernisation plans in 1946 and 1953. Yet, it responded, and was clearly subordinated, to pressing economic and financial problems. One of them was the worrisome contraction of industrial production. At the end of 1945, industrial production at the end of WWII was estimated at half the level of pre-war years. ${ }^{32}$ Rampant inflation was another urgent problem to be addressed by post-war governments, as money supplies had quadrupled over the same period. Farm policy reflected these arbitrages. Although massive investment expenditure was injected into the mechanisation of agriculture, price support was, compared with the subsequent CAP regime, both fairly limited and flexible because governments feared generalised social unrest. Except in isolated instances where governments introduced automatic price increases, intervention prices were kept at a fairly low level, and a system of quantum enabled to modulate support in accordance with the quantities produced. ${ }^{33}$ 


\section{Farm Conflict}

Agrarian syndicalism during this period displayed a continuing tension between the profound appeal of post-war calls to unity and enduring cleavages between 'conservative' and 'leftist' farm leaders. ${ }^{34}$ The creation of the Confédération Générale de l'Agriculture (CGA) in the wake of WWII seemed to put an end to weak and fragmented farm representation. For the first time, one organisation brought together 80 per cent of French farmers. Yet, conflict soon broke out over the structure of the new body and the values it represented, which was compounded by the fact that the CGA had to reckon with a multitude of cooperatives, credit organisations, and specialised (commodity) associations. The architects of the CGA, Socialist Tanguy-Prigent and his colleagues, envisioned a strong role for national-level confederal structures in 'revolutionis[ing] French agriculture'. ${ }^{35}$ Contrary to these expectations, the Fédération Nationale des Syndicats d'Exploitants Agricoles (FNSEA) — the producers' section of the CGA-shortly eclipsed the confederal organisation. The FNSEA, animated by conservative groups, registered a victory in the elections of January $1946 .^{36}$ This victory, however, expressed above all farmer's profound distrust of national leaders and bias in favor of local representatives. Farmers disclosed their 'revulsion against the organisers of the CGA, whose interests seemed to them to be urban and political rather than rural and professional, ${ }^{37}$ Evocations of unity were continuously belied by internal conflict and the FNSEA's ambition to be the only channel of farm representation was shaken in 1959 by the formation of the communist-inspired Mouvement de Défense des Exploitants Familiaux (MODEF). ${ }^{38}$ Unity was postponed.

Protest activity during the 1960 s revealed the fragmentation of farm groups. In one of the few systematic studies of farm protest in France during this period, one observer 
concluded that 'the French peasant never existed' because 'the diversity of agricultural productions isolates him', ${ }^{39}$ thus confirming Wright's prophecy in 1953 that 'agrarian syndicalism is likely to be hampered for years to come by the diversity of the base upon which it rests ${ }^{40}$ Fragmentation resulted first and foremost from the centrifugal effects of market forces. Farmers tended to demonstrate at the end of the working season when they were both physically available for this type of activity and most vulnerable to the fluctuations of the market. ${ }^{41}$ Mobilisation typically clustered in February in wine-growing regions, in March where potatoes were grown, etc. so that no clear pattern emerged at the nationa level. ${ }^{42}$ The pattern of farm protest was thus 'banal' in that the level of protest activity was constant from January to December, rising only perceptibly above the average in October. ${ }^{43}$ Fragmentation also stemmed from the enduring strength of local groups. Pinol noted the absence of correlation between regional levels of farm unionisation and political orientation and farmers' propensity to demonstrate. ${ }^{44}$ French farmers were firmly rooted in local contexts defined by seasonal market cycles and 'native' representation.

CONSOLIDATION OF THE CAP, 1970-1987

\section{The Agricultural Policy Regime}

During this period, national farm policies lost salience as the largest part of agricultural policy fell under the jurisdiction of European institutions. The CAP became a 'living' institution enacted by well-articulated meanings and institutional practices. This new regime endorsed a coherent view of farmers as modern producers, which was rooted in a selective interpretation of the Treaty of Rome. Like post-war policy-makers in France, the architects of the Treaty of Rome considered consimer interests as an important parameter of agricultural policy. ${ }^{45}$ However, the regime emerging from the 1960 s' negotiations departed from these 
considerations by elevating the productive function of agriculture above, and segregating it from, broader socio-economic concerns. In the CAP, agricultural policy loosened its ties to non-farm interests and rested instead on the delicate balance of national farm interests. ${ }^{46}$

The CAP was from the outset a central institution in European integration, judging from the massive amount of resources committed to this domain. Agriculture expenditure amounted to more than 90 per cent of the total EC budget in 1970 and still more than 70 per cent in $1985 .{ }^{47}$ Production-related measures received the lion's share at the detriment of structural measures. From 1970 to 1987 , market policy represented on average 97.25 per cent of EU agriculture budget, the remainder 2.75 per cent being allocated to structural measures. ${ }^{48}$ This distribution reflected the political compromises of the 1960 s, notably the decision to support farm income by guaranteeing agricultural prices rather than by creating deficiency payments. Commodity regimes, formally known as Common Market Organisations (CMOs), represented the building blocks of market policy. These organisations provided for a 'set of coherent and structured mechanisms, whose objective is to regulate a group of agricultural products and the products resulting from the first transformation'. ${ }^{49}$ Intervention agencies were set up for each commodity regime to buy, store, and when necessary destroy products whenever market prices reached a floor level determined in relation to the 'intervention price'. To complement this system, policy-makers created import levies and export refunds to insulate EU farmers from world market fluctuations. Price support created broad imbalances by giving farmers incentives to produce ever more regardless of the environmental, market, and budgetary consequences; nevertheless, it remained intact during this period.

Inertia was in large part due to the organisation and the world-view of the CAP. The CAP promoted the farmer as a 'special' European, requiring extraordinary attention both in 
qualitatively and quantitatively. Agricultural negotiations took place within a distinct formation of the Council of Ministers, the Agriculture Council, where only Agriculture Ministers met. The same specialisation occurred at the lower level of negotiations, where the Special Committee on Agriculture (SCA) acted in place of the Committee of Permanent Representatives (COREPER). Within these insulated structures, incumbents tended to remain longer in office than elsewhere, which contributed to a high degree of socialisation among national agriculture ministers. ${ }^{50}$ The structure of the agricultural policy domain in the European Parliament (EP) accentuated the 'protective outlook' of decision-makers. ${ }^{51}$ Comagri, the Committee on Agriculture, Fisheries and Food, was a 'homogeneous' committee in that its members represented exclusively the farming world. ${ }^{52}$ In the EP as in the Council of Ministers, the problems generated by the CAP were thus externalised, typically by being transferred to structures with little power on agricultural policy, such as the Budgets Committee, the Budgetary Control Committee (Cocobu) and the Land and Use Food Policy Intergroup (Lufpig). Finally, it is commonplace to emphasise the 'baffling' and 'complex' character of farm policy. ${ }^{53}$ The technicality of farm discussions upheld the walls between farming and non-farming worlds in more than one way: by linking understanding of the policy debate to the command of expert language; by emphasising the productive functions of agriculture; and by delegitimising 'political' arguments as falling outside the purview of EU institutions. $^{54}$

Rules and standard operating procedures introduced specific path-dependent effects. Contrary to other domains, agricultural policy took place within highly institutionalised routines, structured by yearly price setting negotiations (so-called agricultural marathons). Price-setting negotiations followed a yearly routine unfolding in three stages. During the first stage (September to November), the Commission examined agricultural prices and elaborated 
proposals for increases product by product on the basis of the 'objective method'. Policy precedents played an important role in this method: the decisions on intervention prices were influenced by past decisions on market regime prices, irrespective of the income trends in other economic sectors. ${ }^{55}$ The proposals were then transmitted for consideration by the Council of Ministers, the EP, the Economic and Social Committee, and European farm organisations in the Comité des Organisations Professionnelles Agricoles (COPA). During the second stage (December to February), consultation took place at the national and the European levels. COPA lobbied the relevant Committees of the EP and sent top representatives (members of the Presidium) to the Plenary Sessions of the Parliament. National farm organisations were active at the national level by lobbying their Agriculture Minister and at the European level through the Economic and Social Committee. During the last stage (March to June), intense bargaining took place among governments of memberstates. Final decisions were reached in the marathon session of the Agriculture Council. These routines effectively allocated the attention of central policy-makers on prices while keeping at bay antagonistic policy interests.

This pattern of intervention contributed to disconnecting farmers from the broader economy. In principle, budget expenses created policy linkages between farm policy and other common policies, but these linkages existed only in dotted lines as a result of the insulated organisation of the decision-making process.

\section{Farm Conflict}

Some have noted that the introduction of US price support programs in the 1930 s increased the power of US commodity groups. ${ }^{56}$ In Europe, the development of price support regimes marked the apogee of corporatist groups-the FNSEA and its sister-organisation Centre 
National des Jeunes Agriculteurs (CNJA) — which used price policy to contain internal conflicts between commodity groups and between competing models of development. Farm protest became the popular arm of corporatism, an instrument of negotiation used by FNSEA and CNJA to influence European bargaining and quell internal conflict.

If protest activity in the 1960s was punctuated by seasonal cycles, the institutionalisation of full-fleshed commodity regimes induced a marked integration of protest activity. In fact until 1988, protest mirrorred both the pace and the organisation of CAP bargaining. As figure 1 indicates, protest activity in the mid-1980s was concentrated during the cycle of price negotiations. Farm mobilisation typically developed in crescendo during the spring, from local to national and European demonstrations. Farm groups targeted primarily their national ministers at home as well as during the sessions of the Council of Ministers, and only rarely the Commission-which explains why protest activity tended to peak late in the cycle of price negotiations. ${ }^{57}$

[Figure 1 about here]

Furthermore, the breakdown of protest data by sector shows that until the early $1990 \mathrm{~s}$ European commodity regimes mediated the role of market factors. Market forces were arguably as fluctuating during this period as they were in the 1960s, but the extent to which they destabilised farmers and triggered contention depended upon the pattern of European market policy. From 1983 to 1993, the rate of activism was thus inversely correlated with the level of intervention: the higher the level of European intervention in a sector, the less were farmers exposed to market fluctuations, the less they were prone to activism. Thus, pig 
farmers and the producers of vegetables and fruits were by far the most active groups while cereal growers were conspicuously absent (figure 2).

[Figure 2 about here]

That farm demonstrations were for the most part routine shows of strength on the part of farm organisations need not mean that they were politically insignificant. Some ministers made it clear that they considered street demonstrations a bargaining tool in the negotiations. ${ }^{58}$ Demonstrations were also dramaturgic acts, through which corporatist groups could 'manifest' the unity of the farming world. ${ }^{59}$ Undoubtedly, the FNSEA and the CNJA were from the beginning plagued by internal contradictions. The antagonism between cereal growers and livestock producers has been one of the most enduring sources of conflict within these organisations. They reached a high point in the early 1970 s when the secretary-general of the CNJA denounced publicly 'the common agricultural policy... which has given more money to the rich in the name of liberalism and economic efficiency ${ }^{7} .{ }^{60}$ Yet, European arrangements consolidated corporatism in several ways. The representational monopoly granted COPA by the European Commission and the FNSEA by national authorities made organisational secession a risky strategy. Besides institutional factors, the European policy regime itself rewarded unity by offering corporatist farm groups to prospect of everincreasing agricultural prices. As long as prices played a key role in the European system of intervention, the FNSEA and the CNJA were able to maintain quiescence among their troops. The advantages of price policy were more tangible for livestock producers than the hypothetical benefits to be reaped from disunity. As some have noted, "this conception of "solidarity" led intensive livestock producers to demand higher prices on meat products 
rather than a decrease in the price of cereals ${ }^{61}$ The strategy of undifferentiated high prices practiced by the FNSEA at home and relayed by COPA at the European level was the "price to pay' for maintaining peace among farm groups_cereal growers and livestock producers, small and large farmers. This explains why a national space of contention emerged during this period around the institutional routines of the CAP despite the deep cleavages crisscrossing farm organisations.

REFORM OF THE CAP, 1988 AND AFTER

\section{The Agricultural Policy Regime}

Two events have acquired a prominent place in studies of CAP reform: the dairy quotas in 1984, and the MacSharry reform in 1992. To many, 'reform can be said to have begun in earnest' with the dairy quotas. ${ }^{62}$ Faced with the prospect of bankruptcy, the EC for the first time agreed to place quantitative restrictions on price support. Quotas entered into effect during the 1984-1985 marketing year, forcing dairy producers to comply with the limits on production imposed by EC institutions on pain of penalties. With hindsight, however, this reform appeared little more than cosmetic change in light of the continuing budget and production imbalances. Thus for others, far-reaching change took place only with the MacSharry reform, 'the most far-reaching in the history of the $\mathrm{EC}^{\prime}{ }^{63}$ This reform sanctioned the role of direct payments as the main instrument of support while introducing significant price cuts for a wide range of commodities, chief among which cereals.

While the significance of these two reforms is beyond doubt, the turning point really took place in 1988 with the introduction of budgetary discipline. These restrictive measures responded to the new obligations contracted by the EC as a result of the signature of the Single European Act and the enlargement to Spain and Portugal. The latter countries had 
insisted during the accession negotiations that they would not be able to participate in the freeing of the internal market... unless the structural funds were substantially increased' ${ }^{64}$ In a path-breaking agreement in February 1988, European institutions committed themselves to a four-year financial perspective which de facto marked the real end of the price support system.

The European Commission was quite right pointing out that budgetary discipline 'set in motion a reorganisation of agricultural market and price policies'. ${ }^{65}$ The 1988 agreement triggered no less than the de-institutionalisation of the price support system. Shifting priorities in the allocation of resources disclosed tangible signs of institutional change. The agreement of February 1988 capped agriculture expenditure while doubling the structural funds. According to the new agricultural guideline, the growth of agriculture expenditure was not to exceed 74 per cent of the growth of the Community's GNP from 1988 to 1992. Member-states adhered to this commitment: the share of agriculture expenditure fell from 70 per cent of the total EC budget in 1988 to 59 per cent in 1993. In fact, agriculture expenditure even fell 2.88 billion ECUs below what the agricultural guideline envisaged in $1992 .{ }^{66}$ Within the agricultural budget, a similar balancing act took place away from traditional areas of intervention to newer areas of concern. The share of agriculture expenditure devoted to Guidance measures rose from 3.3 per cent in 1987 (789.5 million ECUs) to 8.4 per cent in 1992 (2,847.4 million ECUs). ${ }^{67}$ The March 1999 agreement on Agenda 2000 confirmed this twofold trend by elevating rural development measures to a second pillar of agricultural policy and by 'stabilising' agriculture expenditure to a 40.5 billion Euros a year from 2000 to 2006.

Changes in the organisation and the procedures of agricultural policy were also perceptible. Several factors contributed to a slow disenclaving of the agricultural policy 
process. Some institutions, which previously had little or no role in agricultural policy, acquired greater saliency in the emerging discourse on budgetary discipline. This has been the case for the EP which, albeit a minor actor in agricultural policy, has gained a stronger foothold in this domain thanks to the institutionalisation of inter-institutional agreements on the budget from 1988 on. Heightened political sensitivity to budgetary discipline has also benefitted the European Court of Auditors, which has been granted the status of full institution in the Maastricht Treaty. In turn, the Court's growing influence has increased the visibility of the critique of the productivist orientation of the CAP. New actors have also started to change the logic of existing institutions, although this process has been slower. The election in June 1999 of Graefe zu Baringdorf, a Green MEP, to the chairmanship of the EP's Comagri may thus be a sign of departure from the traditional 'one-side' structure of this committee. Finally, the Commission's recognition in 1998 of a left-wing oriented farm Eurogroup, the European Farmers' Coordination (EFC), has enabled farm interests critical of corporatist groups to be represented in socio-professional advisory committees. Signs of an opening up of agricultural policy have thus multiplied in the late 1990s.

Finally, the policy process has become more fluid as a result of the erosion of standard price-related institutional routines. Prior to 1988, the attempts to reform agricultural policy did not fundamentally challenge the role of prices as the main instrument of intervention. In fact as the dairy quotas show, reform was subsumed under the routine procedures governing price setting. The institutionalisation of inter-institutional agreements in 1988 marked the end of spectacular springtime agricultural marathons. No longer encapsulated in price-setting negotiations, the reform process has since taken a course of its own, increasingly subject to the interference of external political factors and the collision of institutional calendars. Where previous rounds of the GATT negotiations failed to make an 
impact on the CAP, the MacSharry reform was tightly intermeshed with the Uruguay Round negotiation. Likewise, the Agenda 2000 has woven together the enlargement negotiations with Central and Eastern European countries with CAP reform.

\section{Farm Conflict}

The reforms of the late 1980 s and the 1990 s have had ambivalent effects on the pattern of farm conflict in France. While reforms blocked the reproduction of dominant farm groups' organisational strategy, they fell short of inducing a complete pluralisation of farm politics.

Data covering the 1988-1993 period show that European policy negotiations continued to play a central role in the formation of farm protest (figure 3). Just like the reform of the dairy quotas elicited a powerful wave of mobilisation in 1984, the MacSharry reform triggered intense protest activity. Close to 200,000 farmers demonstrated in Paris in September 1991 during the discussion of the Commission's reform proposals. This national action inaugurated a period of generalised unrest during which governmental officials were persona non grata in the country. Conflict protracted well after member-states adopted the MacSharry reform in May 1992.

[Figure 3 about here]

The influence of the European policy process on farm conflict was, however, neither predictable nor exclusive of other determinations. In fact, CAP reforms substituted a highly volatile pattern of contention for the previously ritual spring protest campaigns. From 1988 to 1993, contention peaked indiscriminately in February (1993), June (1992), August and September (1990), and October (1989 and 1991). This irregularity reflected the de- 
institutionalisation of key CAP routines and the greater fluidity of the policy process. On several occasions, farmers exploited the collision of domestic and European political calendars to press their claims. For example in September 1991, the fact that French députés were discussing the national budget when farmers besieged Paris explains the redoubled vigor of popular contention. The intersection of institutional calendars enabled French farmers to obtain significant compensations financed on the domestic budget-so-called 'French amendments' to the MacSharry reform - that the European Commission eventually had to accept. Likewise in 1993, protesters were all the more active as the final negotiations of the Uruguay Round collided fatefully with domestic parliamentary elections. More fundamentally, the opening up of the agricultural policy process was an important catalyst of intra- and inter-group conflict and strengthened the critical purpose of farm contention. Farm protest was no longer just the popular arm of corporatism.

The reform of the dairy quotas in 1983-1984 had already spelled troubles for corporatist groups, and played an important role in the decision of minority unions to create EFC in 1986, a European organisation contesting COPA's hegemony. ${ }^{68}$ The MacSharry reform exacerbated tensions among farm groups for obvious reasons. Radical price cuts called into question the delicate balance that corporatist groups had managed to strike between livestock producers and cereal growers. Simultaneously, the shift to direct payments undermined the FNSEA's basic strategy to keep commodity groups under one roof by depriving it from its elementary instrument of internal peace making. Finally, the idea of differentiated prices introduced by the European Commission in the early blueprints for reform legitimised de facto the discourse of left-wing farm groups. Anti-corporatist mobilisation became stronger during this period (figure 4). It was nourished by Coordination Rurale, created in June 1991 under the aegis of right-wing cereal growers. This group waged 
an intense and violent protest campaign, which unfolded almost uninterrupted from the spring 1992 to the end of 1993. Initially, CNJA and FNSEA's local branches lent support to Coordination Rurale. However, the latter entered shortly into conflict with the headquarters of corporatist groups, forcing them to deploy unprecedented efforts to remobilise their grassroots and respond tit-for-tat to Coordination Rurale's demonstrations.

[Figure 4 about here]

While right-wing groups were increasingly visible in street demonstrations, left-wing activists concentrated on building new advocacy networks reaching out beyond farm constituencies at home and abroad. At the European level, EFC settled permanently in Brussels near the headquarters of the European Commission in 1989, from where it has developed informal contacts with like-minded European consumer groups (e.g., Eurocop) and environmental organisations (e.g., European Environmental Bureau/EEB). At the national level, left-wing groups expanded this strategy by creating the Alliance Paysans-ÉcologistesConsommateurs (referred to as 'the Alliance'), a nation-wide network of farm and non-farm organisations, in which Confédération Paysanne plays a pivotal role. ${ }^{69}$ This strategy has yielded some success in the Uruguay Round negotiations as a result of the Alliance's campaign Agir pour une Alternative au GATT (July 1993-April 1994), and in the Millenium Round following joint actions between Attac and Via Campesina, a world peasant movement launched by EFC. ${ }^{70}$

Though a significant trend, the rise of left-wing international advocacy networks in the mid-1990s, like the creation of right-wing farm groups in France in 1991, has thus far fallen short of transforming European farm politics.. Weakened by successive waves of 
secession, the FNSEA and CNJA have nevertheless maintained their hegemony over farm constituencies. They have benefitted in part from the discrepancies between the militant discourse of these groups, the cultural embeddedness of organisational unity among farmers, and the 'technical intervention' of the European Commission where policy is formulated.

\section{CONCLUSION}

This article set out to investigate farm protest in France in relation to broader dynamics of Europeanisation and globalisation. The analytic framework emphasised the dialectic relationship between institutional politics and contentious politics: institutions are the fulcrum of collective action while being changed by it. On this basis, the analysis compared three junctures of the agricultural policy regime, corresponding to different phases of the CAP. These junctures reflected different degrees and modes of socialisation of resources, and they were characterised by changing relations between policy-making elites and ordinary farmers.

During the first period, agricultural policy remained determined at the national level even as the contours of a new policy regime took place at the European level. The modernisation of agriculture served higher priorities inherited from the post-war years such as the need to boost industrial production and quell rampant inflation. As a consequence, intervention on agricultural markets was flexible (there was no guarantee of automatic increase in support from one year to another), and limited (quanta modulated support and prices were kept relatively low). Protest during this period evidenced the fragmentation of farm groups. As market prices accounted for a significant share of farm income, market cycles inspired desynchronized protest cycles from one region to another in accordance with regional patterns of product specialisation. Collective action continued to draw its strength from local solidarities despite the rise of national farm organisations. 
The second period marked the golden age of the CAP as an institution, and its effects made themselves felt on political conflict as well as on policy outcomes. Agricultural policy was a priority of European institutions and benefitted from the largest pool of resources. Routine bargains in the marathon sessions of the Agriculture Council and standard operating procedures such as the 'objective method' had clear path dependent effects on policy. The organisation of agricultural policy turned the CAP into an enclave within which a productivist ethos became safely entrenched. This set-up refracted political conflict by attuning popular mobilisation to the life of CAP institutions and by accelerating the corporatisation of farm representation. High intervention prices subtracted farmers from the volatility of market forces and created greater popular demands on European policy-makers; thus, farm protest during this period offered a faithful reflection of the routine cycles of European policy-making. At the same time, the insulation of the CAP process empowered corporatist organisations at the detriment of dissident groups on the left and on the right while the prospect of ever-increasing prices enabled the FNSEA and the CNJA to achieve a temporary truce among commodity groups. The regional mosaic of contention gave way to nationally integrated patterns of mobilisation. Protest was organised for the most part in line with the instructions of the national headquarters of corporatist groups. It materialised in the form of routine protest campaigns culminating with European demonstrations during agricultural marathons.

The last period witnessed significant changes in the CAP. A landmark in agricultural policy, the agriculture guideline adopted in 1988 de facto symbolised the end of prices as the main instrument of intervention in market policy, and broadened the construal of the CAP beyond the confines of market policy. Later, the MacSharry reform corroborated these orientations by sanctioning the shift from prices to direct payments, the Agenda 2000 by 
promoting rural development as the second pillar of agricultural policy. Institutional routines like agricultural marathons lost significance; they were replaced only in part with new standard operating procedures (e.g., inter-institutional agreements). On the whole, the agricultural policy process became more volatile, and increasingly subject to the interference of broader international negotiations such as the Uruguay Round, the Millenium Round, or the enlargement of the EU to Central and Eastern European countries. The CAP process also became more fluid as new actors and new issues influenced the agenda. Patterns of mobilisation during this period recorded some of these changes. Farmers abandoned routine actions and exploited the opportune collisions of domestic, European, and international calendars to press their claims. Corporatist groups commanded less authority as the European policy agenda legitimised some of the concerns of their opponents while reactivating tensions among commodity groups.

It is now clear that protest took on different roles over time: in the 1960s, it conveyed a demand for public intervention against the encroachment of market forces; in the 1970s, it represented the popular arm of corporatist groups; in the late 1980s and in the 1990s, it adjoined a growing critique of corporatist arrangements and the productivist ethos associated with them. These findings provide a clear, albeit cautious, signal of the erosion of agricultural corporatism in France. Even if corporatist unions continue to command the most sizeable share of the farm population, internal rivalries and successive waves of secession have weakened their pretensions to representational monopoly.

It is also clear that European, and to a lesser extent global, processes have played an significant role in the production and transformation of farm representation and agricultural conflict. Far from being an exception, agriculture is not fundamentally different from the industrial sector in modern democracies, where historical changes in the socialisation of 
income have had a clear impact on the pattern of labor militancy. ${ }^{71}$ The golden age of the CAP marked the apex of trade protectionism and the apogee of agricultural corporatism. The effects of the European policy regime were domesticated by powerful actors in agricultural policy. Likewise, the weakening of corporatist groups can be traced in large part to European processes, and not simply to the arrival of a Socialist government in France as many have argued. The reform of the CAP opened up to some degree the policy process: internally, because it linked agricultural policy to other policy areas in the EU and introduced new issues and actors into the policy process; ${ }^{72}$ externally, because CAP reform took place through a deliberate coupling of the Eurcpean process with larger-regional (enlargement) and global (GATT / WTO)—negotiations.

These findings shed light on the neglected 'European' sources of farmers' protest in France, often portrayed as an idiosyncratic feature of French politics, and of agricultural corporatism in general. Some of these trends seem to have been at work in farm politics in other EU countries, ${ }^{73}$ while studies of contention in the EU have evidenced instances of 'domestication' in other sectors. ${ }^{74}$ These are only the first steps towards a more systematic understanding of the forces which have reinvented traditional European political practices since the post-war. 
FIGURE 1

POLICY CYCLES AND PROTEST CYCLES

\begin{tabular}{llll}
\hline Marketing Year & Commission's Proposal & Council's Decision & Peak of Farm \\
& & & Protest in France \\
\hline $1983 / 84$ & $21-$ Dec-82 & 17-May-83 & April \\
$1984 / 85$ & 12-Jan-84 & 31-Mar-84 & March \\
$1985 / 86$ & 30-Jan-85 & 16-May-85 & March \\
$1986 / 87$ & 06-Feb-86 & 25-Apr-86 & August \\
$1987 / 88$ & 18-Feb-87 & 30-Jun-87 & March \\
\hline
\end{tabular}


FIGURE 2

COMMODITY REGIMES AND PROTEST DIFFERENTIALS

\begin{tabular}{|c|c|c|}
\hline Sector & $\begin{array}{l}\text { Coefficient of Public } \\
\text { Intervention }(1996)^{a}\end{array}$ & $\begin{array}{l}\text { Coefficient of } \\
\text { Activism (1983-1993) }\end{array}$ \\
\hline Arable Crops & 3.77 & .20 \\
\hline Sheep \& Goat & 2.05 & .85 \\
\hline Beef and Milk & .98 & 1.22 \\
\hline Wine & .30 & 1.39 \\
\hline Fruits \& Vegetables* & .22 & 2.14 \\
\hline Pig \& Poultry & .04 & 5.11 \\
\hline
\end{tabular}

Note: ${ }^{\text {The }}$ The cofficient of public intervention is the ratio of the share of each sector in the EAGGF budget and the share of each sector in the final value of agricultural production. ${ }^{b}$ The coefficient of activism is the ratio of the share of each sector in the total sum of protest events and the share of each sector in the total number of farms. Here, the number of protest events is $\mathrm{N}=560$. 
FIGURE 3

SOURCES OF FRENCH FARMERS' PROTEST

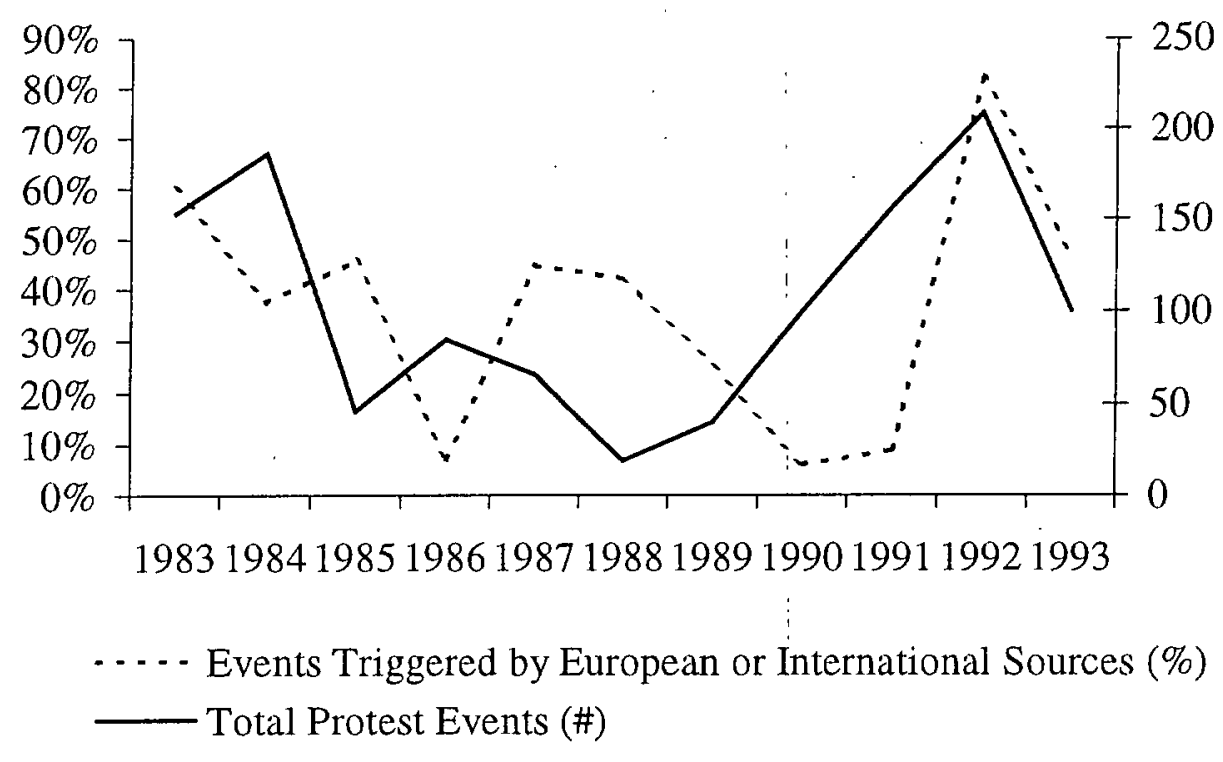


FIGURE 4

PROTEST EVENTS SPONSORED BY MINORITY FARM GROUPS (\#)

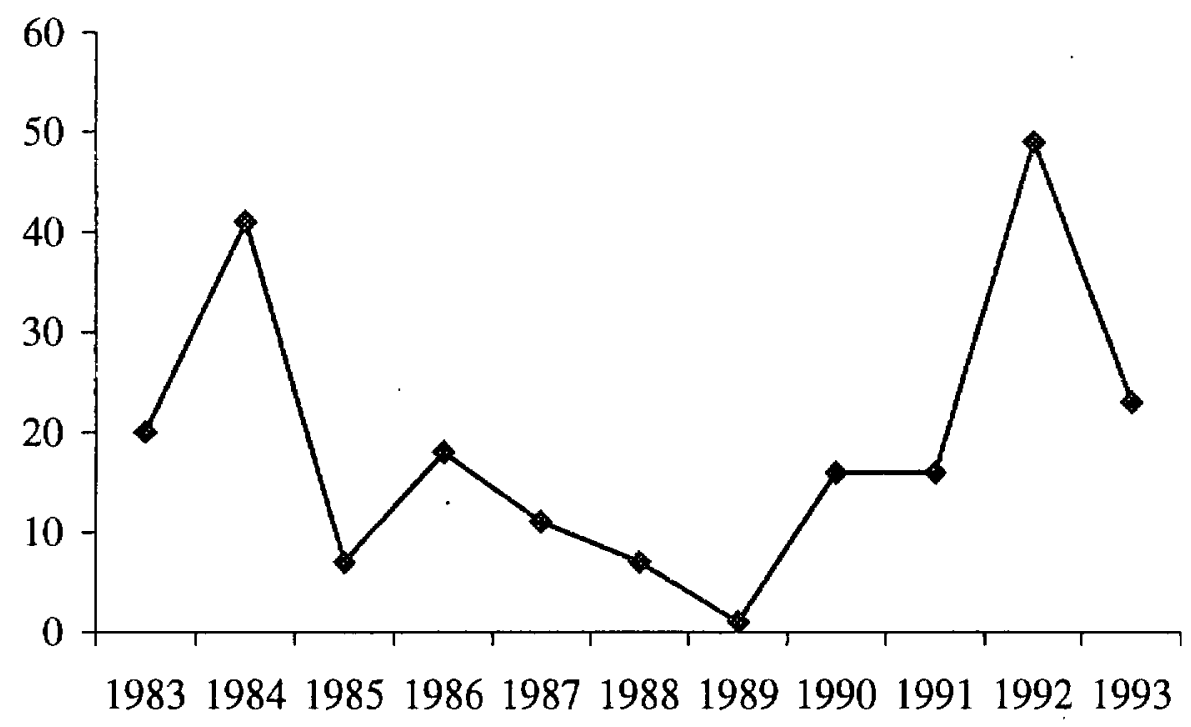


NOTES

1. H. Wallace, 'Europeanisation and Globalisation: Complementary or Contradictory Trends?', New Political Economy 5/3 (2000) p.370.

2. S. Hix and K. H. Goetz, 'Introduction: European Integration and National Political Systems', West European Politics 23/4 (2000) pp.1-26; D. Imig and S. Tarrow, 'Political Contention in a Europeanising Polity', West European Politics 23/4 (2000) pp.72-93.

3. Wallace, 'Europeanisation and Globalisation: Complementary or Contradictory Trends?'

4. B. Laffan, "Becoming a "Living Institution": The Evolution of the European Court of Auditors', Journal of Common Market Studies (1999) 37/2, pp.251-68; J.P. Olsen, 'Organising European Institutions of Governance', Arena Working Paper 00/2 (Oslo: University of Oslo 2000), p.6-9.

5. Vahl, for example, argues that during the MacSharry reform and the Uruguay Round negotiations, farmers were 'indirectly involved in EC decision-making... Compared with the noise made by agricultural interest groups, the voice of employers was only faint', $R$. Vahl, Leadership in Disguise: The Role of the European Commission in EC DecisionMaking on Agriculture in the Uruguay Round (Aldershot: Ashgate 1997), p.150.

6. A. Cox and J. Hayward, 'The Inapplicability of the Corporatist Model in Britain and France: The Case of Labor', International Political Science Review 4/2 (1983); M. A. Schain, 'Corporatism and Industrial Relations in France', in P.G. Cerny and M.A. Schain (eds.) French Politics and Public Policy (London: Frances Pinter 1980); F. L. Wilson, 'French Interest Group Politics: Pluralist or Neo-Corporatist?', American Political Science Review 77/4 (1983), pp.895-910.

7. J. T. S. Keeler, 'Corporatism and Official Union Hegemony: The Case of French 
Agricultural Syndicalism', in S. Berger (ed.) Organizing Interests in Western Europe (Cambridge: Cambridge University Press 1981); J. T. S. Keeler, The Politics of Neocorporatism in France (New York: Oxford University Press 1987).

8. Details on the method can be found in C. Roederer, Popular Struggle and The Making of Europe's Common Agricultural Policy: Farm Protest in France, 1983-1993 (Ph.D. dissertation Columbia, SC: University of South Carolina 2000), pp.293-321.

9. J.G. March and J.P. Olsen, 'The Institutional Dynamics of International Political Orders', International Organization 52/4 (1998), pp. 948; Olsen, 'Organising European Institutions of Governance', p.4-5.

10. K. Thelen and S. Steinmo, 'Historical Institutionalism in Comparative Politics', in S. Steinmo, K. Thelen, and F. Longstreth (eds.) Structuring Politics: Historical Institutionalism in Comparative Analysis (Cambridge: Cambridge University Press 1992), p.3.

11. J.L. Campbell and O.K. Pedersen, 'The Second Movement in Institutional Analysis', in J.L. Campbell and O.K. Pedersen (eds.) The Second Movement in Institutional Analysis: Neoliberalism in Perspective (Princeton: Princeton University Press Forthcoming), p.9.

12. The European Bank for Reconstruction and Development (EBRD) provides a good example of the impact of institutionalised meanings. See S. Weber 'Origins of the European Bank for Reconstruction and Development', International Organization 48/1 p.1-39.

13. M. Lodge "Isomorphism of National Policies? The "Europeanisation" of German Competition and Public Procurement Law', West European Politics $23 / 1$ (2000). Pp.89107. 
14. Y. Surel 'The Role of Cognitive and Normative Frames in Policy-Making', Journal of European Public Policy 7/4 (2000), p.496. On the role of frames, see also B. KohlerKoch, 'Framing: The Bottleneck of Constructing Legitimate Institutions', Journal of European Public Policy 7/4 (2000), pp.513-31.

15. J.G. March and J.P. Olsen, Rediscovering Institutions, (New York: Free Press 1989), p.39.

16. Weber, 'Origins of the European Bank for Reconstruction and Development'.

17. March and Olsen, Rediscovering Institutions, p.42-3.

18. U. Sverdrup, 'Precedents and Present Events in the European Union: An Institutional Perspective on Treaty Reform', Arena Working Paper 98/21 (Oslo: University of Oslo 1998).

19. Olsen 'Organising European Institutions of Governance', p.4; P. Selznick, Leadership in Administration: A Sociological Interpretation (Evanston, Ill.: Row, Peterson 1957), pp.16-7; A. Stinchcombe, Constructing Social Theories (New York: Harcourt 1968), pp.181-2.

20. Sverdrup, 'Precedents and Present Events in the European Union: An Institutional Perspective on Treaty Reform', p.5.

21. Olsen, 'Organising European Institutions of Governance', pp.4-5.

22. Laffan, 'Becoming a "Living Institution": The Evolution of the European Court of Auditors'.

23. Sverdrup, 'Precedents and Present Events in the European Union: An Institutional Perspective on Treaty Reform', p.5.

24. Campbell and Pedersen 'The Second Movement in Institutional Analysis', p.9. 
25. Thelen and Steinmo, 'Historical Institutionalism in Comparative Politics', pp.16-18.

26. J. Pontusson, 'From Comparative Public Policy to Political Economy. Putting Political Institutions in Their Place and Taking Interests Seriously', Comparative Political Studies $28 / 1$ (April 1995), p.140.

27. Pontusson, 'From Comparative Public Policy to Political Economy. Putting Political Institutions in Their Place and Taking Interests Seriously', p.140.

28. S. Phillips, 'Meaning and Structure in Social Movements: Mapping the Network of National Canadian Women's Organisations', Canadian Journal of Political Science 24/4 (1991), p.756.

29. S. Tarrow, Power in Movement (Cambridge: Cambridge University Press 1994), p.85.

30. Electoral instability is a fourth element in Tarrow's definition of political opportunity structure, but it plays a secondary role here given that neither the European Commission nor the Council of Ministers are directly elected. See S. Tarrow, 'States and Opportunities: The Political Structuring of Social Movements', in D. McAdam, J.D. McCarthy, and M.N. Zald (eds.) Comparative Perspectives on Social Movements (Cambridge: Cambridge University Press 1996), pp.54-6.

31. J. Pinder, European Community. The Building of a Union (Oxford: Oxford University Press 1991), pp.146-147.

32. C. Micaud, 'The Launching of the Fourth French Republic', The Journal of Politics $8 / 3$ (August 1946), p.300.

33. P. Barral, Les Agrariens Français de Méline à Pisani. (Paris: Armand Colin 1968), p.322.

34. G. Wright, 'Agrarian Syndicalism in Postwar France', The American Political Science Review 47/2 (June 1953), pp.402-16. 
35. Wright, 'Agrarian Syndicalism in Postwar France', p.405.

36. Wright, 'Agrarian Syndicalism in Postwar France', p.407.

37. Ibid.

38. M.C. Cleary, Peasants, Politicians and Producers (Cambridge: Cambridge University Press 1989), p.138.; B. Hervieu, Les Agriculteurs (Paris: PUF 1996), pp.84-87.

39. M. Pinol, 'Dix ans de manifestations paysannes sous la Cinquième République 19621971', Revue de Géographie de Lyon 50 (1975), p.125.

40. Wright, 'Agrarian Syndicalism in Postwar France', p.415.

41. It was at this moment that they placed their products on the market and earned their income.

42. Pinol, 'Dix ans de manifestations paysannes sous la Cinquième République 1962-1971', p.121.

43. Pinol, 'Dix ans de manifestations paysannes sous la Cinquième République 1962-1971', p.121.

44. Pinol, 'Dix ans de manifestations paysannes sous la Cinquième République 1962-1971'.

45. Article $39 \S 1$ of the Treaty of Rome singled out five objectives: to increase the productivity of agriculture; to guarantee farm income; to stabilise markets; to ensure the security of food supply; and to guarantee reasonable prices to consumers.

46. French producers benefitted from higher levels of protection, resulting from the compromise struck between France and Germany, and the guarantee of automatic support. See R. Fennell, The Common Agricultural Policy of the European Community: Its Institutional and Administrative Organisation (London: Granada 1979), pp.103-4.

47. Budget statistics are from: European Commission, Vademecum: The Community Budget: 
The Facts in Figure (Luxembourg: Office for Official Publications of the European Communities 1999).

48. EU's agricultural budget is the European Agricultural Guidance and Guarantee Fund (EAGGF). As its name indicates, it comprises two broad categories: the Guarantee Section and the Guidance Section, which financed respectively market policy and structural measures.

49. J. Loyat and Y. Petit, La Politique agricole commune (PAC), (Paris: La Documentation Française 1999), p.181.

50. B. Kerremans, 'Do Institutions Make a Difference? Non-Institutionalism, NeoInstitutionalism, and the Logic of Common Decision-Making in the European Union', Governance 9/2 (1996), p.232.

51. W. Grant, 'Pressure Groups in the European Community: An Overview', in S. Mazey and J. Richardson (eds.) Lobbying in the EC (Oxford: Oxford University Press 1993), p.304.

52. Homogeneous committees are opposed to 'both sides' committees which include a variety of antagonistic interests (e.g., the Economic and Monetary Affairs Committee). On this point, see S. Bowler and D.M. Farrell, 'The Organising of the European Parliament: Committees, Specialisation and Co-ordination', British Journal of Political Science 25 (1995), pp. 219-243.

53. A. Swinbank, 'The Common Agricultural Policy and the Politics of European Decision Making', Journal of Common Market Studies, vol. 27 (June 1989), p.29.

54. Roederer, Popular Struggle and the Making of the CAP. Farm Protest in France, 19831993, p. 236. 
55. H. von Witzke, 'Endogenous Supranational Policy Decisions: The Common Agricultural Policy of the European Community', Public Choice 48 (1986), pp.157-74.

56. H. W. Moyer and T.E. Josling, Agricultural Policy Reform: Politics and Process in the EC and in USA (Hemel Hempstead: Harvester Wheatsheaf 1990), p.131.

57. Interview with high-ranking COPA official, 13 December 1999.

58. Interview with high-ranking COPA official, 13 December 1999.

59. M. Berlan, 'Farmers' Wives in Protest; A Theatre of Contradictions', Sociologica Ruralis 26/3-4 (1986), pp.285-303; P. Champagne, 'La Manifestation. La Production de l'Événement Politique', Actes de la Recherche en Sciences Sociales 52-53 (June 1984), p.19-41.

60. Quoted in G. Duby and A. Wallon (eds), Histoire de la France Rurale. Volume 4. (Paris: Seuil 1977), p.655.

61. H. Delorme, 'La Politique Agricole dans l'Internationalisation des Échanges', in P. Coulomb, H. Delorme, B. Hervieu, M. Jollivet, and P. Lacombe (eds.) Les Agriculteurs et la Politique (Paris: Presses de la FNSP 1990), p. 43.

62. M. Tracy, Agricultural Policy in the European Union and Other Market Economies (Brussels, Belgium: Agricultural Policy Studies 1997), p.12.

63. C. Daugbjerg, 'Reforming the CAP: Policy Networks and Broader Institutional Structures', Journal of Common Market Studies $37 / 3$ (September 1999), p.415.

64. S. George, Politics and Policy in the European Union (Oxford: Oxford University Press. 1996), p.187.

65. European Commission, Situation and Outlook: Rural Developments (Luxembourg: Directorate-General for Agriculture 1997), p.66. 
66. B. Gardner, European Agriculture (London: Routledge 1996), p.54.

67. European Commission, Vademecum: The Community Budget: The Facts in Figure.

68. Interview with high-ranking EFC official, 7 December 1999.

69. Confédération Paysanne was born in 1987 from the merging of two left-wing unions: the Confédération Nationale des Syndicats de Travailleurs Paysans (CNSTP) born in 1981, and the Fédération Nationale des Syndicats Paysans (FNSP) created in 1982.

70. Attac, Association for the Taxation of Financial Transactions for the Aid of Citizens, was created in June 1998 following Ignacio Ramonet's call in a December 1997 Le Monde Diplomatique article to resist the liberalisation of financial markets. Confédération Paysanne, one of the founding organisations of Attac, is a member of its executive board.

71. D.A. Hibbs Jr., The Political Economy of Industrial Democracies (Cambridge: Harvard University Press 1987).

72. This point supports the general hypothesis that the post-Maastricht era has been characterised by a more politicised and participatory type of decision-making in the EU; see L. Hooghe and G. Marks, 'The Making of a Polity: The Struggle over European Integration', in H. Kitschelt, P. Lange, G. Marks, and J.D. Stephens (eds.) Continuity and Change in Contemporary Capitalism (Cambridge: Cambridge University Press 1999), p.73.

73. J. Grant, W.A. Maloney, and A.M. McLaughlin, 'Characterising Agricultural PolicyMaking' Public Administration 72 (Winter 1994), pp.505-26.

74. D. Imig and S. Tarrow, 'Political Contention in a Europeanising Polity', West European Politics 23/4 (October 2000), p.79. 
